\title{
Estupro em campo: Reflexões de uma* sobrevivente
}

\author{
Eva Moreno** \\ tradução: Florbela Ribeiro, Karina Coelho, \\ Letizia Patriarca, Paula Bessa \\ Universidade de São Paulo, São Paulo, São Paulo, Brasil
}

REVISÃo TÉCNICA: Thais H. TiRiba

DOI 10.11606/issn.2316-9133.v26i1p235-265

\begin{abstract}
Através do trabalho de campo ao bel prazer da cultura anfitriã aprende-se o próprio lugar ali e esse lugar é o ponto através do qual se penetra na cultura. Erros e infortúnios no campo são ótimas lamparinas de iluminação se sobrevivemos; amizades ali são o único melhor recurso, além de serem um conforto divino. (LANDES, 1986, p. 139)
\end{abstract}

Além do assassinato direto, o estupro é a sanção máxima usada pelos homens para manter os papéis de gênero ${ }^{1}$. $\mathrm{O}$ medo do estupro obriga mulheres a aceitarem restrições em seus movimentos físicos e conduta, e a obedecerem a regras de comportamento que governam a maioria dos aspectos de suas vidas inteiras ${ }^{2}$. Que as mulheres são elas mesmas culpadas pelo estupro é uma noção predominante em muitas sociedades, que decorre da ideia de que é responsabilidade das mulheres garantir que elas não estejam 'no lugar errado na hora

\footnotetext{
1 *[Nota da Tradução] A tradução da língua inglesa para a língua portuguesa nos coloca questões sobre marcações de gênero das palavras e nosso entendimento é de que estas marcações são fundantes da discussão proposta neste texto, acerca do fazer antropológico diversamente marcado para antropólogas e (não) para antropólogos. Portanto, mesmo sabendo que poderiam ter sido outras, explicitamos as escolhas que realiza mos para esta tradução: quando originalmente se lia "anthropologist" traduzimos por "antropólogo"; "male anthropologist" por antropólogo homem e "female anthropologist" por antropóloga mulher - exceto quando as experiências partem da própria autora e nestes casos, também optamos por sempre traduzir como "a" vítima e "a" sobrevivente, como no título, relacionalmente com "o" agressor. ** O nome da autora e todos os outros nomes neste capítulo são pseudônimos.

Estupro sempre implica morte. Neste texto, discuto o estupro como um meio de punir, castigar e corrigir as mulheres individualmente. Homens e crianças ta mbém são estuprados e o estupro é usado em coletivos de mulheres em períodos de guerra, mas esses casos estão além das reflexões feitas aqui.

${ }^{2}$ Veja, por exemplo, a contribuição de Gearing, ta mbém em =Taboo: Sex, Identity and Erotic Subjectivity in Anthropological Fieldwork; orgs. Don Kulick e Margaret Willson, 1995.
} 
errada'. Em outras palavras, há horas, lugares e situações proibidas para as mulheres, que elas atravessam apenas por sua conta e risco.

\section{O estupro e as antropólogas mulheres}

Antropólogos que fazem trabalho de campo em sociedades estrangeiras ou entre grupos pouco familiares se encontram fora dos limites de sua própria ordem de gênero. Eles raramente agem completamente de acordo com as convenções de gênero da sociedade em que fazem trabalho de campo. Um forte problema para as antropólogas mulheres, como eu, é que membros da sociedade anfitriã podem tentar nos forçar à ordem de gênero local, exatamente da mesma maneira como mulheres locais que, intencionalmente ou não, provocam e desafiam a ordem existente são punidas e colocadas na linha. Para algumas antropólogas mulheres, isso pode ser uma situação familiar, já que nós, em nosso contexto de origem, podemos ser vistas como rebeldes recalcitrantes contra uma ordem de gênero que não facilmente permite que mulheres independentes e capazes superem os níveis de prestígio(s) de nossos pares, e onde o assédio sexual é uma medida padrão adotada por homens para manter intacta uma hierarquia de gênero dominada por homens. $O$ potencial de violência sexual contra as mulheres, de assédio a assassinatos relacionados a estupros, está presente em todos os lugares. Em uma situação de campo, o simples fato de que se é uma antropóloga mulher solteira fazendo seu próprio trabalho pode apresentar uma provocação intolerável a alguns indivíduos. Sabendo dos riscos enfrentados por pesquisadoras de campo, é surpreendente que a literatura antropológica seja quase desprovida de referências à violência sexual sofrida por antropólogos.

Há muitas boas razões para este silêncio, algumas delas mencionadas em outras contribuições deste volume. O elemento da culpa que ainda se liga à sobrevivente do estupro, se relaciona ao fato de que mulheres que sofreram violência sexual têm medo de prejudicar sua posição profissional ao falar sobre isso. Entre antropólogos, há frequentemente um pressuposto implícito de que uma antropóloga mulher competente, primeiramente, não deve se colocar em uma posição onde ela poderia ser estuprada (HOWELL, 1990, p. 93). Há também uma visão masculina predominante que iguala a vulnerabilidade à fraqueza, o que faz com que muitas mulheres tenham medo de confrontá-la por medo de serem consideradas antropólogas menores do que nossos colegas homens. No «Ocidente», o estupro ainda é um tema estigmatizado e as vítimas frequentemente esperam (e recebem) pouca simpatia por suas descrições de agressão. A recente reação de alguns colegas a relatos de outros tipos de violência pessoal contra antropólogos em situações de campo, onde a violência era vista de alguma forma como "culpa" do autor, sugere que o silêncio das vítimas de estupro está baseado em suposições razoavelmente precisas (KULICK, 1994). 
Os dois casos de estupro e tentativa de estupro mencionados no livro de Howell levaram à morte das vítimas, o que pode, infelizmente, ser o motivo pelo qual eles são denunciados; já que nenhum dano adicional pode ser feito à vida profissional das vítimas, e elas não podem controlar o que é escrito sobre elas.

Além da preocupação sobre sua reputação profissional, uma outra importante razão para o silêncio sobre o estupro e agressão sexual é que aquelas que sofreram esse tipo de agressão estão muito provavelmente sofrendo com a síndrome do trauma do estupro. Ao descrever o estupro infligido a ela e suas tentativas subsequentes de enfrentá-lo, Cathy Winkler observa que,

os estupradores se sobrepõem não apenas às palavras e ações de suas vítimas, mas também atacam a definição das vítimas de seu corpo e de seu eu sexual. As ameaças dos estupradores vão além de desafios superficiais e invadem mentalmente e psicologicamente os seres e a auto definição das vítimas. (1991, p. 12)

Na melhor das hipóteses, leva muito tempo para se superar a síndrome do trauma de estupro. Tal experiência já é devastadora o suficiente quando ocorre em ambientes conhecidos. Se ela acontece em uma situação como o trabalho de campo, na qual o senso de si mesmo já está sob ataque (WENGLE, 1988), muitas dimensões do trauma, tais como sentimentos de culpa, responsabilidade e auto-aversão, serão ainda mais agravadas. A menos que o propósito da escrita seja terapêutico ou para fornecer um testemunho legal, é quase impossível escrever sobre o estupro antes que o trauma esteja de alguma forma controlado.

Então há puro medo, um medo generalizado da sobrevivente e uma relação insidiosa de medo entre estuprador e sobrevivente que provavelmente durará até a morte de qualquer uma das partes. Para a vítima, é o medo de ser estuprada novamente ou de ser morta. Winkler escreve que "estupradores enterram minas terrestres nos corpos de suas vítimas", minas terrestres que explodem em confusão, náusea, pesadelos, tremores e depressão (WINKLER, 1991). Se a vítima reporta o crime, ela teme retaliação do estuprador. Se o estuprador for levado a julgamento, a sobrevivente não apenas terá que reviver a experiência publicamente e rever o agressor, mas também ele pode ser absolvido do crime e ter a intenção de se vingar dela por tê-lo entregue. E mesmo que o estuprador seja condenado, a sobrevivente sabe que ele logo será solto, talvez pronto para se vingar de sua acusadora.

Vinte anos se passaram desde que os eventos que estou prestes a descrever aconteceram. Depois de todo esse tempo, ainda é difícil escrever este ensaio. É impossível ser um observador participante e um eventual repórter em uma situação em que sua vida e o seu self estão em jogo. Suas emoções e seu equilíbrio profundamente perturbado são muito pessoais para serem trocados por 
créditos antropológicos ${ }^{3}$. No entanto, o tempo faz de fato diferença. Eu posso olhar para trás para a jovem que eu era, com tristeza e medo, mas também tolerância e uma profunda gratidão às pessoas no campo que interferiram e ficaram ao meu lado. Agora sinto que devo àquela jovem mulher que eu era, e a muitas outras antropólogas iniciantes, recontar essa história da maneira como eu a entendo após duas décadas tentando enfrentar o que aconteceu e por quê.

\section{Uma experiência de campo}

Fui pela primeira vez para a Etiópia em 1964 por um período de cinco semanas. Eu tinha 20 anos e fui impulsionada pela forte paixão por um estudante etíope na Suécia, meu país de origem. Um ano mais tarde, voltei como membro do Serviço Voluntário Sueco para trabalhar por dois anos como cientista social em uma organização técnica financiada pelo auxílio ao desenvolvimento. Depois desses dois anos, retornei à Suécia para terminar meus estudos de graduação em sociologia, mas voltei à Etiópia por vários meses em 1968 com a finalidade de realizar o trabalho de campo para minha pesquisa final.

Quando voltei a Etiópia, em fevereiro de 1972, para realizar trabalho de campo para minha tese de doutorado, tinha utilizado esse intervalo para me aprofundar na antropologia social cujo conhecimento africanista não encontrei na sociologia sueca. $\mathrm{O}$ objetivo da minha pesquisa era fazer um estudo urbano, na pequena cidade sulina de Ketema, usando tanto questionários quanto entrevistas de história de vida. Para fazer este trabalho, eu precisava de um assistente para me ajudar, de preferência uma pessoa com um alto nível de educação e um bom domínio do inglês.

Eu teria preferido trabalhar com uma mulher, e eu repassei isso a meus contatos na universidade e em outros lugares. Minhas redes trouxeram duas candidatas para o trabalho; mas no final, nenhuma das duas estava interessada em prolongadas jornadas fora da capital. Para a maioria das pessoas jovens e educadas na Etiópia, viver fora da capital era extremamente pouco atrativo. Se o trabalho "nas províncias" não era atraente para os homens jovens, era quase impossível para as mulheres jovens. Meninas educadas, como todas as meninas pertencentes à classe alta, eram mantidas, tanto quanto possível, junto a suas famílias até se casarem. As poucas que não estavam sob a proteção de suas famílias tinham outras preocupações que as impediam de deixar o ambiente urbano.

\footnotetext{
${ }^{3}$ Em sua contribuição para a inovadora antologia "Mulheres em campo", Diane Freedman escreve sobre como ela retornou ao campo logo após a morte de seu marido, e como foi sobrecarregada com informações sobre morte e luto, enquanto seus informantes tentavam consolá-la. Ela não podia tomar notas e nem fazer uso profissional de tudo isso. Era a vida real, destinada a ela, não moedas para o mercado antropológico (FREEDMAN, 1986).
} 
Por fim, eu tinha dois rapazes entre os quais escolher, ambos sugeridos pelos meus contatos na universidade. Um era vários anos mais novo do que eu, estudante de sociologia, com um penteado afro alto, calças boca de sino, nervoso na entrevista: a própria imagem de um dândi da cidade. O outro - a quem chamarei Yonas - era um homem da minha idade, vestido e penteado de forma discreta, com experiência anterior como pesquisador de campo em uma das agências governamentais nacionais. Yonas afirmava ser politicamente interessado (o que na época significava que ele era de esquerda) e não parecia nervoso enquanto conversamos. Tanto Yonas, quanto meu outro possível assistente, tinham sido expulsos da universidade recentemente, o mais jovem pela primeira vez, Yonas pela terceira.

Ser expulso da universidade era comum naquela época de tensão política, quando os estudantes universitários na Etiópia assumiram a liderança nos protestos contra regimes políticos autocráticos. Ser expulso três vezes, no entanto, era peculiar. Na época, porém, interpretei isso como um sinal de que Yonas estava tomado por um zelo louvável na busca da verdade e da justiça - uma interpretação sem dúvida encorajada pelo próprio Yonas. Depois de alguma ponderação sobre qual dos dois homens escolher, finalmente decidi por Yonas, com base nesse zelo, em sua experiência, em sua aparente calma e em seu interesse declarado pelo estudo.

Desde o início do meu relacionamento com Yonas, tive problemas com autoridade. Na minha cabeça, e consequentemente no meu comportamento e fala, várias concepções conflitantes de autoridade foram sobrepostas. $\mathrm{Na}$ minha própria sociedade, diferenças de classe social e econômica certamente existiam, mas eram apenas sutilmente marcadas. Nos anos 1940 e 1950, a existência de diferenças de classe na Suécia havia sido ignorada na retórica política oficial. Isso mudou drasticamente na década de 1960. O aumento da conscientização sobre as diferenças de classe impulsionou as tentativas de eliminar seus marcadores e minar a dinâmica social e econômica que reproduzia as desigualdades de classe. Este esforço foi realizado de muitas formas, tanto oficialmente como informalmente, desde reformas de longo alcance no sistema educacional, até a abolição do formal e educado pronome de tratamento vous no discurso.

Nos locais de trabalho, isso significava extinguir os marcadores de posição social. Um campus universitário recém-construído, por exemplo, não tinha espaços reservados para refeições ou reuniões exclusivas do corpo docente; as mesmas condições foram aplicadas a todos. Embora nós nunca chegássemos ao ponto de nos dirigir uns aos outros como "colegas", os títulos não eram mais usados na comunicação pessoal, e os funcionários de todos os escalões de uma organização usavam os primeiros nomes para se referirem uns aos outros.

Mas as coisas não eram realmente o que pareciam ser. Sob a proferida igualdade, todos sabíamos bem quem era o chefe e quem era o subordinado; 
quem decidia e quem era obrigado a seguir "sugestões". Tudo o que fizemos foi deixar de lado os marcadores mais óbvios de classe e status. Isso funcionou, de um estranho modo, porque os suecos eram um povo relativamente homogêneo com uma religião, uma língua e uma raça; descendentes dos dois terços que foram deixados para trás enquanto a parte mais ousada migrou para os Estados Unidos na virada do século.

Além dessa postura confusa e contraditória em relação à autoridade que eu trouxe comigo de casa, também possuía uma familiaridade, principalmente em nível subconsciente, com os modernos sistemas etíopes de estratificação. A Etiópia era, e ainda é, uma sociedade extremamente complexa onde diferentes tipos de hierarquias se cruzam, se reforçam e se contradizem umas às outras. $\mathrm{Na}$ década de 1960, a mais proeminente dessas hierarquias era a hierarquia política (“feudal”), com o Imperador no ápice. Os parentes do Imperador compunham as camadas superiores dessa hierarquia ${ }^{4}$. Outras hierarquias eram as étnicas, as religiosas, a baseada na educação secular moderna e a baseada na riqueza. Sobrepostas a todas elas estavam as ordens de gênero, que eram distintas para cada grupo étnico, incluindo uma ordem de gênero separada para o setor "moderno" urbano da sociedade, onde eu havia me estabelecido.

Essa intrincada rede de hierarquia permeava todos os aspectos da vida social. Estava em toda parte e era continuamente reforçada por práticas de deferência e dominação que eram inescapáveis se você fizesse parte da sociedade etíope. Certamente, meus companheiros etíopes no exterior e na capital se horrorizavam com a exploração aberta e impiedosa construída e continuada pelas múltiplas hierarquias; no entanto, eles - e eu junto com eles - éramos parte do sistema e desempenhávamos nossos papéis quando lidávamos com ministros, mendigos, funcionários, chefes, servos, prostitutas, corretores, ladrões, maridos e esposas.

Sem ter consciência disso, eu havia adotado as mesmas atitudes e comportamentos de meus amigos e companheiros de classe média etíopes em relação às pessoas ao meu redor. Involuntariamente, esperava o mesmo tipo de reação dos subordinados que eles esperavam e recebiam. Eu não percebi que o status que mantive quando morei antes na Etiópia tinha sido obtido por associação à organização para a qual eu trabalhava e ao status dos etíopes aos quais eu me associava. Inicialmente, minha interação com outros na forma de uma pesquisadora estrangeira solitária, equipada com um carro e com autorizações e certificados oficiais, parecia fazer a maioria das pessoas aceitar o status que eu reivindicava.

\footnotetext{
${ }^{4}$ Veja, por exemplo, Markakis (1974) para uma descrição da autoritária política etíope anterior a 1974, ou Kapuscinski (1983) para uma perspectiva da atmosfera em torno do palácio imperial.
} 
Depois de três meses na Etiópia, e um mês trabalhando com Yonas em alguns arquivos na capital, todos os preparativos estavam prontos e eu finalmente me mudei para Ketema, com Yonas a reboque.

Ketema há vinte anos era uma cidade movimentada, se expandindo quase que em tempo real. Tinha cerca de 12.000 habitantes, de todos os principais grupos étnicos no país. Sua estrutura era típica de uma cidade de beira de estrada africana; um cinturão estreito de prédios de tijolos de um andar com telhados de zinco que se estendia por um quilômetro à beira da estrada. Em nenhum ponto a cidade adentrava mais de 500 metros de distância da rodovia.

Os habitantes de Ketema ganhavam a vida através do comércio, comunicação, serviços e administração. A cidade era um lugar de recém-chegados, dividida por marcações de classe, etnia, religião e vizinhança. Ela atendia viajantes e comerciantes; era cheia de lugares onde comer, dormitórios, 'boates', e abrigava muitos bares de um só cômodo, administrados por mulheres solteiras que serviam cerveja local - e elas próprias - sob demanda. Havia também alguns bancos, muitos postos de gasolina, duas escolas primárias e uma escola secundária, uma delegacia de polícia, um mercado médio aberto diariamente e um grande mercado semanal. Você poderia comer em Ketema por valores que iam de 5 centavos de dólar americano a 1.5 dólares; você poderia passar a noite em um dormitório por 10 centavos ou em um hotel altamente respeitável por 2 dólares.

Quando Yonas e eu chegamos em Ketema, decidi ficar no hotel respeitável. Eu aluguei um quarto para Yonas no mesmo lugar, assim deixando clara a igualdade (assumida) em nosso relacionamento desde o início. Assim que nos instalamos no hotel, a primeira tarefa com a qual me deparei foi encontrar algum lugar para morar. Eu achava que, como antropóloga, era esperado que eu morasse com uma família ou que tivesse toda uma casa para mim. Afinal de contas, quem entre nós não ficou chocado com os rumores de antropólogos veteranos que trabalham nos hotéis? Eu percebi depois que na situação em que estava em Ketema, a coisa mais óbvia seria estabelecer um acampamento permanente em um dos hotéis mais simples. Mas eu não enxerguei o óbvio. Eu estava determinada a fazer as coisas de acordo com o manual e, assim, comecei a procurar uma casa.

Depois de ter considerado as habitações disponíveis na própria cidade, eu decidi por uma casa a poucas centenas de metros de distância da cidade, apesar dessa decisão não se encaixar na minha ideia de uma residência antropológica ideal. A casa era próxima à cidade, agradável, espaçosa e cara. Era uma construção de pedra, erguida por um oficial de uma subdivisão vizinha a Ketema, para sua eventual aposentadoria. Nesse meio tempo, ele queria alugá-la a custo correspondente a seu empréstimo bancário. Com a casa vieram o tio do oficial e sua esposa, que moravam nas dependências dos empregados nos fundos e que cuidavam dela quando estava vazia. De um lado da casa havia um hotel 
inacabado, do outro, um terreno utilizado para plantar batatas.

A casa era grande o suficiente para mim e meu assistente, então convidei Yonas a se instalar em um dos quartos. A razão para tal era que eu não podia me dar ao luxo de encontrar um outro lugar razoável na cidade para ele. Além disso, todavia, também senti que me sentiria muito solitária à noite, então queria ele por perto para que houvesse alguém com quem conversar. Eu indaguei sobre a conveniência desse arranjo com Yonas porque eu temia que o fato de residirmos juntos pudesse sinalizar para as pessoas da cidade que o relacionamento entre mim e ele era mais do que de empregadora-empregado. Yonas me disse que as pessoas na cidade suporiam que nós mantínhamos relações sexuais, independentemente de dividirmos a casa ou não, e que, portanto, eu deveria escolher o arranjo que fosse mais prático. Minha preocupação foi aliviada pelas reações do velho tio Benjamin, o caseiro. Benjamin obviamente não pensava que Yonas e eu éramos um casal; em vez disso, ficou claro que ele percebeu Yonas como uma espécie de combinação entre segurança e membro da equipe.

Em Ketema, por ser uma cidade de beira de estrada, era possível adquirir todos os itens essenciais. Em pouco tempo, eu tinha montado escritório, quartos e cozinha com a ajuda de uma locadora local e alguns fortes trabalhadores contratados.

Logo no início, passei a questionar seriamente se Yonas seria adequado ao trabalho de assistente de campo. Ele era grosseiro, mal-humorado, elogiava-me excessivamente e tinha o hábito de se gabar - frequentemente sobre como ele havia vencido alguém que o insultara. Isso era desagradável. Em retrospectiva, ameaçadoramente estranho. Mas o tempo era curto e senti que eu não tinha uma alternativa real para substituí-lo. Esperei pelo melhor, amparada por experiências positivas anteriores de relações de trabalho com jovens rapazes superficialmente similares a Yonas.

Em uma das primeiras noites em Ketema, enquanto ainda estávamos no hotel, Yonas apareceu em meu quarto vestindo apenas sua roupa íntima. Este foi o primeiro indício, para mim, de que sua interpretação sobre a nossa relação era bastante diferente da minha. Para Yonas, ele explicou, havia chegado o momento de eu me tornar sua amante. Não levei a sério o seu avanço e facilmente o afastei ao reiterar minha posição: a de que eu possuía um companheiro permanente em casa e que não tinha intenção de ter outros relacionamentos enquanto estivesse na Etiópia. Sem mais protestos, ele voltou ao seu quarto.

Retrospectivamente, parece inacreditável que diante de tal acontecimento eu não tenha tido uma reação mais definitiva. Pensando agora, percebo que, como uma mulher jovem, estava tão acostumada aos avanços indesejados dos homens, que considerei a proposta de Yonas até "normal". Nunca me ocorreu que, como sua empregadora, eu tinha, na realidade, condições de exigir que ele parasse de me incomodar com seus pedidos de sexo. Ademais, como parte de minha própria bagagem cultural, eu vivenciava uma surpreendente ausência 
de medo. Minha geração de jovens mulheres na Escandinávia sentia-se segura, e estava segura ${ }^{5}$, em nossos próprios países. Levávamos nossa despreocupação conosco do Ártico até o Saara, sem temer nada, e geralmente saíamos ilesas. Talvez nossa própria inocência nos protegesse. Além disso, eu não havia recebido nenhum treinamento de campo relevante, nem tinha colegas mais experientes, em casa ou em campo, para quem eu pudesse pedir conselhos. Ademais, eu também estava tranquilizada pelo galanteio cavalheiresco que tinha vivenciado durante meus anos anteriores na Etiópia. O que eu não percebi era que, durante aqueles anos, eu parecia muito jovem para meus amigos etíopes. Eles frequentemente me viam como uma adolescente - isto é, inexperiente e precisando de proteção. Mas agora, quatro anos depois, eu era claramente uma mulher madura, sem marido ou homem defensor por perto. Eu parecia, portanto, disponível.

De todo modo, no que diz respeito a Yonas, este foi claramente o caso e logo sua empreitada foi iniciada. Por várias semanas, esta consistiu numa incômoda insistência - intermináveis "porque não?" - e no descaso pelas minhas persistentes recusas - que se tornavam cada vez mais determinadas, precisas e exasperadas, conforme o tempo passava. Eu não entendia a razão pela qual ele não desistiria. Ele não entendia a razão pela qual eu não iria ceder.

Enquanto tudo isso acontecia, a coleta de dados estava em curso. Meu objetivo era identificar o maior número possível de respondentes de uma pesquisa domiciliar que havia sido feita vários anos antes pela agência nacional de estatística. Eu queria verificar a confiabilidade da técnica de pesquisa aplicada em um local como Ketema e também observar possíveis indícios de diferentes tipos de mudança na população.

Para ajudar com este trabalho, eu havia empregado um mensageiro de meia idade do Centro de Desenvolvimento Comunitário. Ele era o explorador: andava pela cidade com uma lista de respondentes, inicialmente procurando aqueles que já conhecia e, depois, localizando outros, como em uma bola de neve. Seu trabalho foi crucial; além de obter informações de oitenta por cento dos respondentes originais, ele também explicou o estudo a eles, convencendo-os a participar de uma segunda entrevista e agendando o momento do encontro. O mensageiro, Yonas e eu entrevistaríamos então o respondente com uma versão modificada do questionário original.

Conforme o tempo passava, sentia que a minha presença não era necessária durante as entrevistas, e passei a deixar Yonas e o mensageiro cada vez mais responsáveis pela sua realização, enquanto eu me dedicava à checagem

\footnotetext{
${ }^{5}$ Não estou sugerindo que não havia violência sexual contra mulheres na Escandinávia naquela época, mas apenas que sua incidência era baixa - muito baixa se comparada, por exemplo, aos Estados Unidos.
} 
e organização dos dados compilados. Eu estava, aos poucos, recuperando as habilidades que tinha com a língua quando saí da Etiópia em 1968, mas ainda não dominava a arte de conduzir uma entrevista formal com estranhos. $\mathrm{Na}$ situação pouco natural de uma entrevista formal, eu percebi que estava falando Amharic como se fosse Swedish, em uma maneira estranha aos etíopes, como se eu ainda estivesse, na realidade, falando uma língua estrangeira. Além disso, quase nenhum dos respondentes havia falado com um estrangeiro anteriormente, e a experiência os afetava bastante. Alguns simplesmente não me ouviam e apenas me olhavam, ou murmuravam que não falavam inglês. Apenas após estímulos das pessoas que observavam as entrevistas (sempre havia gente observando), eles ouviam e respondiam, mas a situação os deixava claramente desconfortáveis. Eu não teria conseguido levar adiante, sozinha, este trabalho. Não que Yonas fosse exatamente um bom entrevistador; era muito direto e brusco. Sem as preparações anteriores feitas pelo mensageiro, nós provavelmente teríamos tido um número alto de recusas. Como entrevistador, Yonas parecia estar condicionado pela sua atuação anterior como oficial, quando interrogava em situações em que os respondentes não podiam escolher se queriam participar ou não. Neste ponto do trabalho, contudo, eu ainda não estava ciente das falhas de Yonas como entrevistador. Essa descoberta veio depois, quando pude comparar seu estilo com o de outras pessoas que trabalharam comigo.

Após semanas de perturbação diária, Yonas se acalmou e, por um tempo, pensei que houvesse desistido da conquista sexual. Depois entendi que ele havia apenas mudado de estratégia. Agora ele estava decidido a demonstrar a mim que a sua presença era imprescindível para o meu trabalho. No quadro que ele pintou, as pessoas da cidade associavam o estudo a ele, e não a mim. Ele me levou a acreditar que nosso mensageiro receberia apenas ordens dele, e que eu teria que começar tudo de novo, do zero, em outra cidade, caso ele decidisse se demitir e me deixar.

O que acontecia na cidade eu não sei. Já estava acostumada a ser observada, a pais de crianças apontarem a ferenji, a estrangeira, a seus filhos. Ketema não era um local amigável. Era uma cidade de desconhecidos, com diferentes idiomas e hábitos, cheia de preconceitos e suspeitas mútuas. Embora eu me sentisse desconfortável em ser ignorada pelos habitantes, eu não estava surpresa. Culpava a minha própria inaptidão e timidez inerentes. Cada vez mais eu sentia que vivia numa redoma de vidro, com pessoas de fora olhando para mim e eu, de dentro, olhando para elas, mas sem contato real ou comunicação genuína.

Quando concluímos dois meses de trabalho em Ketema, eu começava a me sentir bastante abalada. Minha apreensão por conta de meu isolamento era agravada pela brutalidade de Yonas, que parecia piorar a cada dia. Ele gritava assustadoramente em seus pesadelos, facilmente audíveis do meu quarto, que era ao lado do dele. Quando ele saía à noite, passou a levar uma arma. Isto me 
preocupava, ainda que eu soubesse que os homens etíopes se orgulhavam de andarem armados, e que eu frequentemente visse homens educados da capital levando suas armas quando saíam da cidade. Minha preocupação era com o que Yonas, em seu estado agitado e grosseiro, poderia fazer com a sua arma.

Sem autoridade efetiva, tentei manejar a situação com técnicas semi-psicológicas que eram insignificantes, ineficientes e condescendentes naquelas circunstâncias. Por exemplo, pensando ou esperando que se eu demonstrasse confiança geraria confiabilidade, eu não trancava a porta do meu quarto. Óbvio que, uma noite, acordei com Yonas no meio do quarto me acusando furiosamente de dormir com todos exceto ele.

Não lembro de como repeli esse avanço em particular, mas Yonas deixou o quarto após reclamar em voz alta durante alguns minutos sobre minha discriminação sexual contra os etíopes. Ele acreditava que eu era promíscua: por que, ele exigia saber, eu não seria promíscua com ele? A partir de então passei cuidadosamente a trancar meu quarto, com um sentimento amargo de fracasso e culpa.

Até que, um dia, Yonas anunciou de repente que se demitiria. No dia seguinte, ele partiu.

No início, sua decisão de deixar o trabalho me deixou em pânico. Sua insistência contínua de que eu dependia dele havia me influenciado profundamente: eu não tinha dúvida de que meu trabalho em Ketema estava ligado à sua pessoa e que eu teria que começar tudo de novo em outra cidade. Passados meses desde o início do trabalho de campo, eu ainda parecia totalmente incapaz de estabelecer relações com qualquer pessoa. Os habitantes eram distantes; ainda que muitos respondessem nossas perguntas, eles o faziam com pouco entusiasmo e as entrevistas não levavam a nenhum contato futuro. Eu acreditava que era porque as pessoas da cidade não queriam nada comigo.

Além de Yonas, as únicas pessoas em Ketema com quem eu tinha algum tipo de relação social eram Benjamin, um velho guarda que vinha, por assim dizer, atrelado à casa, e sua esposa. Benjamim era um soldado aposentado de setenta e tantos anos que costumava estar a serviço do Imperador. Ao se aposentar, um pedaço de terra próximo a Ketema lhe havia sido prometido, onde ele poderia cultivar para seu sustento. Uma vez lá, entretanto, os oficiais locais não honraram sua reivindicação e ele foi deixado sem meios de subsistência. Era firme a sua opinião de que "se o rei soubesse" as coisas seriam corrigidas. Mas ele não tinha como entrar em contato com o rei e, enquanto esperava por intercessão imperial, ele aceitou a posição de guarda para a casa do seu sobrinho. Não que ele gostasse do sobrinho, cuja riqueza aparente implicava avançados níveis de corrupção, mas...

A esposa, Sofia, era muitos anos mais nova que ele. Quando nos conhecemos, eles viviam juntos há um ano. Ela tinha apenas um olho, era enérgica, engenhosa e realista. Ela via o velho homem como um sonhador crédulo, mas 
um bom homem, respeitável pela sua bravura e sua idade avançada. Ela disse a Yonas que teve ofertas de homens mais ricos e, por conseguinte, mais atraentes, mas ela sentiu que era seu dever permanecer com o velho soldado, que, em sua opinião, não poderia cuidar de si sozinho.

Eles tinham uma relação tranquila e amigável. Sofia complementava a renda cozinhando para lares mais ricos diversas vezes por semana. Ela também destilava bebidas em um alambique, composto principalmente por varas de bambu, cabaças e esterco. O casal consumia muito da própria produção; frequentemente me chamavam para tomar um pouco, em meu trajeto de ida ou de vinda do banheiro. ("Bom para o coração!"). O que eles não bebiam ia para alguns dos bares simples da cidade. O homem, ainda, contribuía para a sua renda alugando um pedaço de terra onde ele plantava cereais para uso próprio e para o mercado.

Sofia me ajudava a lavar, limpar e fazer compras. Ela era muito interessada nos afazeres das outras pessoas, era animada e falante, o que a tornava uma ótima fonte de informação sobre a vida cotidiana em Ketema. Através dela eu aprendi muitas coisas, inclusive algumas das estratégias que as pessoas usavam para gerenciar suas economias.

Benjamin levava sua guarda a sério. Quando eu informei que Yonas não iria mais trabalhar para mim e que ele havia deixado a casa, ele não fez comentário algum. Mas na mesma noite, quando era hora de dormir, ele veio à casa com seu casaco grande e um cobertor (e um gatinho para fazer companhia), e fez sua cama no chão em frente à porta do meu quarto. Fiquei comovida, é claro, mas também profundamente envergonhada. O guarda não titubeou; não haveria outro modo de me manter segura à noite, ele explicou: caso algo acontecesse, ele não poderia me ouvir da sua casa, e era sua responsabilidade saber o que ocorria. Na manhã seguinte, ele juntou suas coisas e voltou para casa.

Após alguns dias sozinha, já começava a me recompor, e, para minha surpresa, passei a me sentir aliviada pela partida de Yonas. Parecia que eu estava finalmente saindo do que havia se tornado uma situação insuportável. Mudar de cidade poderia não ser uma má ideia. Eu estava começando a pensar que eu poderia começar novamente com um assistente de qualquer outra cidade em que eu escolhesse trabalhar. Uma preocupação real, contudo, era o curto tempo de que dispunha para meu trabalho de campo. Meu projeto inteiro já havia sido adiado substancialmente por causa da reação do governo da Etiópia a alguns artigos críticos que meu supervisor havia publicado em jornais suecos. Por conta desses artigos, meu visto de pesquisadora tinha sido congelado, e eu passei nove meses em casa, esperando pelo visto e, consequentemente, usando a verba da bolsa de pesquisa. Mudar para uma nova cidade e recomeçar seria arriscar ficar sem dinheiro. Entretanto, meu plano era apenas o de ser menos ambiciosa, e tentar fazer o maior uso possível do material que já havia sido coletado em Ketema. 
Nesse momento, quando eu estava começando a me sentir feliz com a perspectiva de recomeçar, Yonas voltou. Ele retornou indiferente, como se nada tivesse acontecido, para saber se eu havia mudado de ideia. Claro que, me disse, ele nunca quis realmente sair. Ele estava apenas incomodado por eu não dormir com ele. Mas agora ele estava pronto para trabalhar novamente.

Apesar do alívio que senti quando Yonas saiu, percebi que aceitá-lo de volta seria uma solução 'fácil'. Em breve eu iria passar um mês de férias longe da Etiópia. Yonas e o mensageiro poderiam continuar a fase de re-estudo sozinhos, pensei. Em um mês, a primeira fase da investigação teria terminado. Algum tipo de estudo parecia possível ainda que eu tivesse abandonado completamente a ideia de realizar um trabalho de campo com a profundidade que eu pretendia, ou da forma como eu imaginava que todos os antropólogos faziam. $\mathrm{Eu}$ aceitei o retorno de Yonas.

Voltei à Etiópia um mês depois e encontrei a situação em Ketema assim como eu a havia deixado. Yonas estava, se é que isso era possível, pior do que antes, e retomou sua empreitada de conquista sexual imediatamente. Ele começou a portar sua arma em casa. Olhando ameaçadoramente para mim, ele a punha sobre a mesa, junto com seu estoque de balas - cinco ou seis - e as polia, tentando ao mesmo tempo me impressionar com o perigo do potencial uso da arma. Recusei, histericamente, a admitir a mim mesma que essas pequenas demonstrações de armamento me preocupavam. Gradualmente, meu senso de realidade foi se desfazendo até que eu me tornei tão preocupada com Yonas, seu humor, suas ameaças e suas súplicas quanto ele estava obcecado por mim e por minha resistência aos seus desejos.

Nossa situação lembrava a de uma esposa espancada e seu agressor. Vendo de fora, eu poderia ter saído da situação a qualquer momento. Mas dentro do ciclo lançado pela nossa relação grotesca, eu não tinha habilidade de me defender de suas manipulações. Eu não conseguia entender o que acontecia, apenas que Yonas parecia controlado por uma ideia fixa e neurótica e não poderia ser alcançado por nenhum argumento ou razão. Tudo o que eu podia esperar era que a primeira fase do estudo logo se completasse, para que eu tivesse uma desculpa para encerrar, de algum modo, minha associação a Yonas.

Tentando superar o grande estresse que eu sentia, encontrava pretextos para visitar a capital. Também fugia regularmente para a escrita e a leitura, e não conseguia me decidir sobre os próximos passos da investigação. Melancolia.

Finalmente, um dos meus mais antigos amigos etíopes conseguiu romper com a minha inércia. Eu havia passado em seu escritório na capital para um café e uma conversa. Casualmente contei a ele, como uma piada, sem dúvida, sobre a cena do polimento da bala. Minha situação em Ketema estava assumindo uma estranha qualidade de normalidade, conforme minha visão do trabalho de campo antropológico afastava-se de vista. A reação do meu amigo Michael foi certeira: 'Livre-se desse homem de uma vez! Se você não fizer 
isso ele pode te matar'. Michael me ofereceu emprestada a sua arma. Para ele, a situação era muito séria para eu estar desarmada. Eu recusei, mas voltei a Ketema finalmente compreendendo que eu estava em perigo.

Ainda assim, eu não estava disposta a demitir Yonas. Os vários meses em Ketema nos prenderam numa pavorosa disputa de arbítrio, sobre quem de nós seria aquele a definir nossa relação. Essa batalha me deixou com um sentimento de que Yonas era inevitável. Vários meses antes, contudo, eu havia conhecido duas mulheres expatriadas que viviam em uma cidade do entorno, Woha, a 20 quilômetros de distância. Elas estavam alojadas em um serviço da British Overseas Aid e da World Health Organisation (WHO), e já haviam trabalhado por mais de quinze anos na Ásia e na África. Buscando temporariamente escapar da minha redoma de vidro, eu ia visitá-las durante os fins de semana, o que me proporcionava uma imensa libertação das pressões de "casa”. Eu tinha um carro, e a mais nova das duas tinha um quarto vago. Ketema ficava a menos de 20 minutos de carro. Para romper com o nosso lar incompatível, eu decidi deixar Ketema e aceitar a oferta de alojamento da mais jovem, ainda que esse ato me parecesse como traição final a minha própria ideia neurótica e fixa - a do trabalho de campo "conforme manda o manual".

Na manhã de 4 de outubro, eu disse a Yonas que estava me mudando e que o faria no dia seguinte. Para minha surpresa, Yonas pareceu aceitar o novo arranjo. Mas na mesma noite eu acordei. Alguém estava batendo a minha porta. Acendi a luz e olhei para meu relógio. Era uma da manhã.

"O que é?"

"Sou eu, Yonas! Estou sendo comido vivo. Me passa o repelente!"

O repelente? Estava no meu quarto? Por que estava no meu quarto?

Vesti um roupão. Repelente em mãos, destranquei e abri minha porta. Yonas empurrou a porta com toda a sua força e forçou sua entrada em meu quarto.

O tempo parou. Meu quarto era bem grande e vazio. Minha cama estava no canto. A janela que dava para o jardim estava fechada por dentro. O guarda Benjamin estava dormindo na sua própria casa, fechada e inacessível, a 20 metros de onde estávamos. A parede externa do frontão não tinha janela. Estávamos sozinhos.

Yonas me agarrou, minha roupa, meu cabelo. Eu estava paralisada. Tudo o que eu consegui fazer foi recuar para dentro do quarto, tentando soltar as suas mãos da minha garganta.

E então eu gritei. Ou, melhor, alguém em mim gritou. Eu me ouvi gritar - um grito desarticulado, não pedindo por ajuda; mas estridente, alto, como uma sirene. Meu corpo inteiro parecia ter vida própria, recusando-se a mover, a chutar, a se defender - a fazer qualquer uma das coisas que eu sabia que poderia fazer. E aquele grito horrível. Mesmo enquanto eu me escutava, percebia que não havia ninguém que o pudesse ouvir. Havia uma horta de batata do lado de fora da casa, mas ninguém estava lá. Benjamin não ouvia bem e, de 
todo modo, havia três paredes e vários metros entre nós; sua esposa também não poderia me ouvir. E se alguém ouvisse? Yonas havia me dito várias vezes que as pessoas acreditavam que éramos amantes; homens regularmente batem em suas esposas; eles ficariam do lado de Yonas, achando que eu merecia o que quer que estivesse acontecendo comigo.

Yonas não fez nenhum progresso comigo. Éramos da mesma altura, ele não era mais pesado que eu, nem mais forte. Meu corpo estava duro como um tronco de árvore. E prosseguia com seu estridente, perfurante grito.

O suor frio escorria pelo rosto de Yonas e fazia suas mãos ficarem escorregadias. Seus olhos estavam enormes, esbugalhados, loucos. Ele estava fora de si, com raiva e determinação. Inalcançável.

Ele vestia um pijama listrado com bolsos. De um desses bolsos ele tirou sua arma, quase relutantemente, tomando cuidado para onde apontava para não atirar nele mesmo acidentalmente. Andando alguns passos para trás, ele apontou a arma para mim.

Os gritos pararam. Minha mente e meu corpo se uniram com a percepção de que minha vida estava em risco, quer ele atirasse deliberadamente ou não. Se a arma disparasse acidentalmente, eu poderia sangrar até a morte.

Enquanto eu olhava para o cano da arma tive a sensação de estar diretamente sob a noite negra e sob as estrelas frias e distantes, calma, lúcida, a minutos da morte, talvez segundos. E para quê? Uma ideia fixa, uma determinação maníaca de não desistir, de manter a definição de quem eu era a todo custo?

Yonas começou a falar. Ele disse que desde que eu havia decidido deixar a casa em Ketema ele sabia que essa seria a última chance de me possuir. E que ele me possuiria agora, não importava o que lhe custasse. Ele não se importava mais se viveria ou se morreria, contanto que ele finalmente me possuísse. Eu respondi, friamente e paralisada, que ele podia ter tudo o que quisesse, qualquer coisa.

Precisamente naquele momento, houve uma tremenda batida na janela. Vozes altas, muitas vozes, golpeando, berrando. Yonas momentaneamente perdeu o rumo. Ambos ficamos estarrecidos. Quem poderia ser? Quem? Para mim, foi como se o escuro céu se abrisse e anjos descessem para interferir. Uma fração de segundo passou. Então Yonas recuperou-se e começou a berrar ordens para as pessoas lá fora. Ele tinha certeza absoluta que o obedeceriam.

'Voltem para as suas camas!', ele ordenou, 'ela apenas teve um pesadelo. Ela está bem. Vão embora!'

Eles não o obedeceram prontamente. 'Nós não conseguimos ouví-la!', gritaram de volta, 'ela está morta! Você a matou!'

Yonas foi mais categórico, 'Voltem para as suas camas! Eu estou dizendo, ela está bem!'

O barulho cessou. Minhas esperanças morreram. Foi como eu temia; os anjos eram de classe inferior a Yonas; eles teriam que obedecer. Eles acreditariam no que ele dissesse. 
Mas então as vozes voltaram, gritando, 'nós não conseguimos ouví-la! Estamos chamando a polícia!"

Enquanto isso acontecia, Yonas manteve a mira da arma em mim, me conduzindo de volta à cama. Seu frenesi parecia alimentado em parte pela interferência lá de fora. Ele descarregou um fluxo aparentemente sem fim de palavras, acusações e explicações. Ainda fora de si, trêmulo, suando frio, com os olhos arregalados, ele me contou sua versão de nossa pesquisa de campo desde o momento em que decidiu candidatar-se para o trabalho. Ele despejou sobre mim palavras que eu havia dito para tentar afastá-lo, e enfatizou minha determinação em não ir para a cama com ele, mas ele distorceu minhas palavras, interpretou-as de modo oposto ao que era minha intenção dizer. Tudo o que eu havia dito ele entendeu em relação à imagem que ele tinha de mim, a de uma mulher indiscriminada e promíscua.

Eu me movi em direção à cama e me sentei. Ele veio em minha direção mantendo-me na mira da arma, e continuou a falar, interrompendo seu discurso apenas para lançar ordens ocasionais para as pessoas lá fora, que agora voltavam a bater na janela. Ele baixou as calças de seu pijama. Eu levantei meu roupão e minha camisola. Com meus genitais à vista ele deteve seus movimentos por um momento.

Ele se deitou em cima de mim mas teve problemas com a arma. Ele tentou empurrar a arma entre nossos corpos para ter certeza de que tinha o controle enquanto me estuprava.

Mas ele chegava ao limite de sua capacidade. Não era possível fazer tudo ao mesmo tempo: manter-me dominada, contar sua história, tranquilizar as pessoas lá fora e penetrar uma mulher relutante.

No momento em que nossos genitais se tocaram ele ejaculou. Eu acho. É possível que sua ereção tivesse acabado e toda aquela umidade fosse apenas uma reação do meu corpo ao estupro. Eu não sei.

Então o frenesi de Yonas acabou. Suas características voltaram ao normal. Seus olhos tornaram-se novamente compreensíveis. Ele estava assustado. Ele queria ser reconfortado, então sentou no meu colo com a arma ainda em suas mãos, mas não mais apontada para mim. Passado um tempo ele subiu suas calças do pijama, foi até a porta da frente e a destrancou permitindo que as pessoas vissem com seus próprios olhos que eu estava viva e estava 'bem'.

Deve ter sido assustador ver Yonas descabelado, suando e com uma arma em mãos. As pessoas lá fora recuaram. Tudo que sabiam era de que ele tinha um cadáver lá dentro.

Então Benjamin deu um passo à frente, com toda a autoridade de um soldado real, ereto/direito e alto. 'Me deixe entrar para vê-la', ele ordenou.

Yonas obedeceu. Então deu meia volta e se apressou para voltar para o seu quarto, trancando a porta ao entrar.

Benjamin entrou no meu quarto e estendeu seus braços em minha direção. 
'Minha querida filha', ele exclamou, 'ele te estuprou'?

Eu caí em seus braços, não chorando, mas tremendo incontrolavelmente. Eu queria sair da casa imediatamente. Me vesti de forma apressada, com dificuldade.

Benjamin passou pelo quarto de Yonas para pegar um copo d'água para mim. Assim que ele voltou da cozinha, Yonas saiu do seu quarto, novamente frenético, preparado para atirar. O velho homem ficou entre nós, e disse para Yonas voltar para o seu quarto. Ele voltou, e eu saí em direção ao carro e dirigi por vinte minutos até Woha onde encontrei refúgio com Sally, uma de minhas duas amigas estrangeiras.

Eu nunca mais vi Yonas.

Eu soube mais tarde que assim que parti, Yonas saiu de seu quarto novamente e concordou em entregar sua arma para o velho homem. Benjamin imediatamente levou a arma para fora e a enterrou sob o chão de terra de sua própria casa. Então ele trancou as portas do meu quarto, da cozinha, e do escritório para que Yonas não pudesse entrar em qualquer cômodo além do seu próprio quarto.

De manhã, Yonas pediu para entrar nos outros cômodos, alegando que tinha coisas pessoais no escritório. $\mathrm{O}$ velho homem não permitiu que ele entrasse, dizendo que eu tinha trancado as portas e levado as chaves comigo quando parti. Ele temia, assim como eu, que Yonas pudesse destruir o material que nós já havíamos coletado. Yonas então foi embora para Woha, à procura de abrigo com alguns amigos da mesma etnia dele que eram professores e oficiais naquela cidade.

\section{Perspectivas sobre o estupro}

Qualquer forma de estupro diz respeito a poder e dominação masculina. A partir da literatura, parece que a forma mais comum de estupro é quando um homem viola uma mulher que ele já conhece. Um cenário frequente é aquele em que um homem se considera no direito de fazer sexo com uma mulher que não aceita o que ele percebe como uma obrigação sexual. Esses homens que exigem ter suas expectativas satisfeitas, alimentam seu senso de que têm o direito de obliterar as vontades de mulheres sob seu domínio (BROWNMILLER, 1975). Vendo sob essa perspectiva, o que aconteceu comigo em Ketema difere pouco do que acontece a milhares de mulheres anualmente em cada país do mundo.

No entanto, Ketema fica na Etiópia, e uma interpretação do ultraje deve ser peculiar àquele país e aos círculos aos quais eu e Yonas pertencíamos. As diferentes interpretações etíopes enunciadas para mim imediatamente depois dos eventos me ajudaram a sobreviver, suportar e eventualmente retomar uma vida normal - mas diferente - como antropóloga. A abertura que encontrei foi desencadeada pela agressão em si mesma, seguida por meu ato de tornar a 
situação pública, pela gratificação genuína que as pessoas sentiram ao apontar o que eu deveria ter feito, e, eu acho, pelo fato de que Yonas tinha quebrado uma série de tabus.

\section{A justificativa de Yonas para o estupro}

O seguinte relato, de como Yonas justificou seu ato e intencionou despejar sua vingança sobre mim, me foi dado pelo próprio Yonas durante o estupro, como descrito acima. Ainda que durante o estupro ele parecesse estar completamente fora de si com fúria e determinação, ele estava absolutamente lúcido, claro e compreensível em seu discurso. Ele queria ter certeza de que eu entendia exatamente o que ele estava dizendo. O que ele me contou ficou marcado na minha memória, devido à situação extrema, devido ao choque que eu senti enquanto ele me fazia entender que eu havia sido manipulada e manobrada por ele desde o início de nossa relação.

Muito tempo depois, eu me perguntei sobre a necessidade de Yonas me contar por que ele deveria me estuprar. Talvez não fosse tão surpreendente. Quando o estupro é punição, então certamente deve ser indispensável para o agressor assegurar a si mesmo que o objeto sabe porque ela está sendo punida ${ }^{6}$. O que segue é a essência do que Yonas disse durante a situação do estupro; essa é a sua visão, da forma como a colocou.

Yonas tinha assumido o trabalho como meu assistente de campo e aceitado a perspectiva de meses de trabalho nas províncias porque ele queria ter uma amante estrangeira. Esse foi o pressuposto pelo qual ele veio trabalhar comigo. Ele não disse por que estava tão interessado em ter uma mulher estrangeira. Eu só posso presumir que ele havia comprado a imagem que circulava entre alguns grupos etíopes de que mulheres estrangeiras, não-circuncisadas, e independentes eram sexualmente aventureiras e promíscuas. Ele queria que eu entendesse que não existia outra razão pela qual ele havia assumido o trabalho como meu assistente de campo.

Desde o início de nossa relação eu tinha, na visão dele, insinuado que uma relação sexual era uma possibilidade real; nós apenas teríamos que esperar pela hora e lugar certos. Ele citava, textualmente, minhas falas e escolhas de palavras que em numerosas ocasiões confirmaram sua crença de que eu tinha intenção de eventualmente atender a seu desejo. Sua memória era espantosa. Eu senti uma imensa vergonha quando ouvi minhas próprias palavras precisamente repetidas, mas distorcidas para implicar significados nunca intencionados. Ele começou a procurar significados e colecionar sinais de que eu cederia, e continuou até começar a suspeitar que ele seria 'enganado'.

Yonas acreditava veementemente que uma mulher nunca vai revelar suas

${ }^{6} \mathrm{O}$ homem que estuprou Winkler também falou a ela longamente. 
verdadeiras intenções para um homem; por isso, tudo que eu disse a ele, ele entendeu de todas as maneiras, exceto a literal. Todos os seus amigos, e sua namorada na capital, acreditavam que nós estávamos vivendo juntos como amantes. Por isso sua namorada o tinha deixado. O mundo apontou os dedos para ele. Ele se sentiu profundamente humilhado e fracassado quando presumiram que ele era meu amante. Em sua visão, ninguém teria acreditado se ele dissesse que não era verdade. (Eu duvido que ele tenha se esforçado para informar seus conhecidos sobre o verdadeiro estado das coisas. Não sendo capaz de seduzir tal pessoa sexualmente voraz como ele tinha se convencido que eu era, não teria melhorado sua imagem como homem).

Ele tinha certeza que eu tinha feito sexo com multidões de outros homens. Ele me espionou na capital, e outras pessoas o ajudaram a me seguir. Ele sabia exatamente quem eu tinha encontrado. Eu encontrei muitos homens brancos desacompanhada; isso significava que eu tinha dormido com eles.

Foi nesse ponto que eu descobri a origem de meu isolamento em relação às pessoas da cidade. Yonas me explicou que ele queria me manter dependente dele. Por essa razão, ele trabalhou ativamente para me manter isolada em Ketema. Com muito gosto, ele me contou como as pessoas tinham-no procurado muitas vezes porque elas estavam interessadas em me conhecer e saber sobre o que era meu trabalho em Ketema.

Ele disse para elas que eu não estava interessada nas pessoas da cidade, que eu não queria conversar ou ter algo a ver com elas. Ele foi explícito neste ponto, querendo que eu soubesse quão inteligente ele tinha sido em me manter atrelada a ele. Ele provavelmente também encontrou satisfação em me fazer entender quão completamente eu estava sob seu poder. Ele poderia fazer meu trabalho acontecer ou acabar com ele.

Ele ficou profundamente desapontado e perplexo quando eu não correspondi a minhas 'promessas' de sexo. Ele chegou à conclusão de que o meu povo era preconceituoso com homens que não eram brancos. Preconceito racial tornou-se a única explicação possível para eu sistematicamente recusar suas investidas sexuais. Ele concluiu que suecos são tão propensos ao preconceito racial quanto americanos ou britânicos, de quem não se podia esperar nada melhor?

Uma vez que ele entendeu que eu não iria satisfazer o que ele via como

\footnotetext{
${ }^{7}$ Eu não encontrei esse tipo de interpretação de outro homem etíope. Etíopes têm muita consciência de cor, mas o branco certamente não está no ápice da hierarquia de cor. Quando trabalhei como voluntária para o Serviço Voluntário Sueco, um número de colegas de trabalho etíopes me contou que suas famílias tinham medo que ela/es pudessem se casar com um/a estrangeiro/a e por conseguinte 'estragar o sangue' da família. Na mesma linha, etíopes gostam de contar para estrangeiros/as que Deus, quando criou a humanidade deixou de lado tanto o homem preto quanto o branco, preferindo o Etíope marrom, que foi criado exatamente com a cor 'certa'. As acusações de racismo feitas por Yonas podem ter surgido de conversas com seus a migos que foram alvo de preconceito racial fora da África.
} 
suas demandas legítimas, ele começou a planejar sua vingança. Ele me contou que estava planejando o ataque há meses. Ele de fato explicou todo seu plano antes de concluí-lo, pois ele estava tão certo de que eu estava sob seu poder, que ninguém acreditaria em mim. Eu acho que ele tinha medo que eu pudesse não entender que esses eventos tinham acontecido porque ele quis e porque ele estava com absoluto controle.

Yonas não apenas manipulou o passado, mas teve a intenção de controlar o futuro também. Foi assim que ele previu a cadeia de eventos subsequentes ao estupro: eu o demitiria. Já que tínhamos um contrato de trabalho, ele então me levaria à justiça por violá-lo. Ele contestaria meu direito de demiti-lo. Eu iria dizer, então, que ele tinha me estuprado. Ele negaria a acusação e ninguém acreditaria em mim. Eu pagaria a ele uma grande indenização por demiti-lo injustamente e teria, talvez, que contratá-lo de volta. Minha humilhação em suas mãos seria então total.

Cerca de seis semanas antes do ataque, ele tinha me pedido para fazer algumas alterações em nosso contrato. Eu não entendi o motivo para isso naquele momento, mas vi depois como essas mudanças, que na realidade tornaram mais difícil para mim encerrar sua contratação, consolidavam o plano de Yonas. Quando eu inesperadamente anunciei para ele que eu estava desmontando a casa, eu o levei a isso. Ele teria ou que executar seu plano naquela última noite ou perder a oportunidade.

A história de Yonas transbordou dele enquanto andava de um lado para o outro em frente à janela fechada, gesticulando com a pistola e pausando de vez em quando para ordenar que as pessoas lá fora fossem embora. Eu estava sentada na ponta da minha cama, esperando o que iria acontecer em seguida. De certa maneira, eu não acho que eu realmente acreditava que Yonas completaria o estupro com as pessoas lá fora podendo nos ouvir. Ao mesmo tempo, no entanto, eu não me importava. Toda a minha preocupação era sair viva da situação.

Assim que o fogo dele apagou e ele retornou ao seu senso normal, Yonas parou de falar.

\section{As reações de Benjamin e Sofia ao estupro}

Benjamin e Sofia depois me contaram que eles não tinham ouvido meus gritos. Mas, do outro lado da cerca que separava a minha instalação dos campos de batata havia um acampamento temporário de trabalhadores agrícolas, homens que tinham sido contratados para colher batatas. Benjamin os tinha visitado quando chegaram, e os convidou para ficarem dentro da propriedade.

É significativo que nem Yonas nem eu 'lembramos' desses trabalhadores agrícolas. Na Etiópia, nem todo mundo é uma pessoa, um alguém. Serventes, pobres, pedintes, pessoas pertencentes a grupos étnicos de baixo status e pagãos não contam. Da maneira como eu tinha entendido, pessoas abaixo de sua própria classificação étnica, econômica ou ocupacional não eram 
consideradas como 'pessoas', enquanto que aqueles que são iguais ou estão acima sempre eram. Se você fosse um 'ninguém' você não seria notado pelos seus superiores. Yonas sabia que os colhedores de batata estavam lá. Mesmo assim, ele claramente não os reconheceu como pessoas que poderiam intervir e, por conseguinte, ele foi em frente com seu plano como se o campo estivesse, de fato, vazio. Ele tinha simplesmente esquecido deles.

Mas o campo não estava vazio, e meus gritos despertaram imediatamente os trabalhadores. Através de Benjamin, eles sabiam muito bem quem eu era. Eles também sabiam que o velho homem se considerava meu principal guardião. Por isso eles não perderam tempo e forçaram a cerca e acordaram o velho homem de seu sono.

Benjamin ficou horrorizado com a agressão de Yonas. Nem por um instante ele acreditou que eu tinha relações sexuais com Yonas. Depois do estupro, repetidas vezes, ele se queixou amargamente de como Yonas o tinha decepcionado. 'Eu confiei nele como confio em mim', ele disse, 'Eu tinha certeza que você estava segura com Yonas na casa. Senão como poderia ter deixado vocês dois sozinhos lá!'

Uma vez que o velho guarda tinha despertado, ele veio em meu socorro imediatamente. Ele disse que ele e os outros estavam certos de que eu tinha morrido, por causa da maneira como meus gritos ecoaram e então pararam completamente. Mesmo assim, todos eles hesitaram em trazer a polícia até que soubessem com certeza o que tinha acontecido.

Eu estava profundamente comovida com o raciocínio de Benjamin e sua solidariedade incondicional comigo. Eu provavelmente devia minha vida a ele ${ }^{8}$, e pude vê-lo colocando sua vida em risco por mim.

\section{A reação dos homens ao estupro}

Como o estupro se tornou conhecido em Ketema, eu recebi uma série de reações de homens e mulheres. A maneira como os homens reagiram dependeu do quão perto eles estavam tanto de mim quanto do drama em si de e como eles viam Yonas.

Benjamin, como eu acabei de colocar, estava chocado e preparado para agir. Ele não manifestou nenhuma opinião sobre o que eu deveria fazer em seguida; até onde entendi, ele achou que meu próprio choque e quase colapso eram reações corretas e adequadas ao que tinha acontecido. Ele concordou que ele tinha de fato salvado a minha vida e reconheceu a profunda obrigação a que eu estava agora sujeita por causa disso.

A única pessoa que insistiu para eu ir à polícia foi um homem jovem da

\footnotetext{
${ }^{8}$ Não importam quais fossem os planos de Yonas antes do estupro, eu honestamente acredito que se estivéssemos sozinhos ele não teria sido capaz de se livrar da situação sem me matar.
} 
cidade, um adolescente que eu tinha apoiado desde meus dias como voluntária. Esse homem ficou muito chateado quando eu escolhi não dar queixa do estupro à policia. Havia muitas razões por trás da minha decisão de não dar queixa à polícia. Na hora do estupro, no meio da noite, a principal razão era de que o único outro estupro de uma mulher estrangeira que eu tinha ouvido até o momento tinha ocorrido em uma delegacia, tendo os policiais como estupradores. Eu tinha receio de que a polícia local pudesse simplesmente continuar de onde Yonas tinha parado. Mais tarde, outros motivos se tornaram mais importantes, tais como não querer ficar retida na Etiópia por meses, talvez anos, esperando por um julgamento incerto. Meu medo do que poderia acontecer se Yonas fosse absolvido era muito grande. Eu senti que seria bastante provável que ele quisesse vingança se eu tentasse denunciá-lo. Na verdade, meses depois eu recebi um bilhete anônimo de Yonas, entregue no correio de Ketema, contendo uma única linha, 'pare suas calúnias, ou então.'

Entre outros homens da cidade, mais distantes, o consenso parecia ser que algo como estupro iria necessariamente acontecer. Eu me lembro de um funcionário público me dizendo que Yonas e eu éramos como um touro jovem e uma novilha trancada em um curral. Quando perguntei por que ninguém me alertou sobre o que eles viam como uma inevitabilidade, ele respondeu, 'Você nos conhece, conhece nossos hábitos e nossa cultura. Nós não quisemos te ofender vindo com conselhos.'

Uma vez que o estuprou ocorreu, eu não notei mudança no comportamento das pessoas com quem eu regularmente tratava. Tais como o velho mensageiro, oficiais do banco local, do correio, etc. Eu descobri que Yonas não era nem um pouco querido por eles. Sua arrogância e tentativas bem sucedidas de me manter isolada não lhe geraram nenhum amigo.

Um dia após a agressão, depois que eu decidi definitivamente que eu não queria envolver a polícia, um gerente do banco da cidade vizinha de Woha concordou em agir como intermediário, para me ajudar a terminar minha relação de trabalho com Yonas. O motivo pelo qual eu precisava contatar Yonas novamente é que sua história sobre como ele poderia me processar pedindo indenização me assombrava. Até que nossas relações contratuais fossem dissolvidas, eu vivi em pânico absoluto pensando no que ele poderia fazer em seguida. Talvez ele encontrasse uma forma de me levar até à justiça para exigir a compensação oficial que ele tinha sonhado. Ou talvez o fato de que ele não pôde me penetrar durante o estupro o deixou em uma posição pior do que quando ele era meramente rejeitado. Ele tentaria novamente então? Ou ele me mataria para me calar?

O gerente do banco encontrou Yonas dois dias depois do ocorrido. Ele negou que qualquer coisa tivesse ocorrido; ele contou ao banqueiro que ele não podia entender por que eu não queria continuar trabalhando com ele. Ele queria muito continuar sendo meu assistente. Yonas pareceu completamente 
calmo e sensato, não havia indicação de que as coisas não fossem como ele as apresentou. $\mathrm{O}$ gerente acreditou nele.

O gerente então me acompanhou de volta a Ketema para eu buscar algumas coisas e para descobrir o que tinha acontecido depois que eu parti. A casa estava exatamente da mesma forma que a deixei quando saí apressada no meio da noite. Benjamin não tinha aberto as portas do meu quarto e do escritório desde então. Quando o banqueiro viu a confusão no meu quarto, tufos de cabelo caídos ${ }^{9}$, e os restos de minha camisola rasgada, ele se desculpou. E se ele ainda tinha alguma dúvida sobre a veracidade de minha história ele poderia ser convencido por Benjamin, que estava pronto para contá-la. Essa foi a primeira vez que eu descobri como meu resgate tinha sido organizado.

As reflexões do gerente foram, então, representativas do que me disseram muitos outros homens. 'Nós, etíopes, só estupramos mulheres que conhecemos', ele explicou. Seu conselho foi o de que eu não deveria ter permanecido em um mesmo lugar por tanto tempo. Eu acho que o tempo máximo para não correr o risco de ser estuprada eram três semanas. Para poder escapar do assédio, eu deveria ter me movimentado entre as cidades, trabalhando tanto quanto eu pudesse nesse tempo limitado. Ele não percebeu que eu tinha passado ilesa pelas mãos dos homens locais de Ketema. O fato é que Yonas era muito mais parecido com o gerente do banco do que com os locais. Ouvindo outros relatos de ameaças e agressões entre mulheres antropólogas e voluntárias na Etiópia, depois ficou claro para mim que o risco mais sério sempre vem de oficiais, assistentes e namorados - pessoas pertencentes à classe de homens educados e 'modernos' de quem mulheres estrangeiras têm maior probabilidade de depender e com quem têm maior probabilidade de fazer amizade.

Quando eu protestei, dizendo que nenhum trabalho de campo sério poderia ser feito pulando de um lugar para outro, ele sugeriu que a única alternativa restante era 'fazer o que nossas mulheres fazem'. Obedecer e se ajustar. Criar uma 'família' e ficar dentro de seus limites, protegida por parentes homens e empregados. Isso foi justamente o que Benjamin havia tentado fazer por mim, quando criou um grupo de proteção para garantir que nenhum homem mal intencionado pudesse me atingir. Aos olhos de Benjamin eu não havia errado ao deixar Yonas ocupar um quarto dentro da casa. Pelo contrário, era Yonas que deveria ser culpado e punido por não ter cumprido seu papel de protetor.

Outra pista sobre o complexo da conquista sexual e da dominação masculina me foi dado por um antigo conhecido que, lamentando o fato de não ter me pedido em casamento quando nós mantivemos relações de trabalho seis anos antes, me explicou que ele não deixou claras suas intenções naquele momento porque não estava certo de que eu o teria aceitado. 'Você sabe', ele

${ }^{9}$ Eu não senti Yonas arrancar meu cabelo enquanto tentava me dominar com suas mãos. 
me disse, 'nós não perguntamos até termos certeza de que seremos aceitos. É difícil para um etíope lidar com a rejeição'.

Uma dimensão do estupro que incitou os homens a desprezarem Yonas foi o fato de ele ter usado uma arma. Estupro é uma coisa, eu vim a aprender, usar uma arma para dominar uma mulher é outra. Isto, para muitos homens, foi o que tornou este estupro particularmente indesculpável e vergonhoso. Homens deveriam dominar mulheres com as palavras e com o dula, um grande pau que é um instrumento comumente usado para ataque e defesa, um que se parece mais com um taco de baseball do que qualquer outra coisa. Muitas vezes ouvi homens da Etiópia repetirem um ditado, 'Com burros e mulheres você fala com o dula ${ }^{\prime 10}$.

Parece então, para alguns homens que comentaram o estupro, que a verdadeira masculinidade que seria provada com o estupro foi colocada em xeque pelo uso da arma. Que tipo de homem era esse, que não conseguia dominar uma mulher sem uma arma? Nesse ponto eu tive a inquestionável empatia dos homens. Armas implicavam morte, o que era algo bem diferente de provar seu ponto a uma mulher relutante.

Em uma visita a Etiópia muitos anos depois do estupro, descobri que a prática legal etíope não reconhecia 'estupro' como um crime contra mulheres a não ser que a mulher em questão fosse comprovadamente virgem. Isso era verdade nos anos 70 e ainda é verdade nos dias de hoje.

\section{Reações das mulheres ao estupro}

O estupro em Ketema alterou completamente as minhas relações com as mulheres na Etiópia. Minha entrada na sociedade etíope deu-se através dos homens. Durante os meus primeiros anos no país, trabalhando como voluntária, todas as pessoas que trabalhavam comigo eram homens. Quando eu juntei material para o artigo final da minha pesquisa, em 1968, todos os meus contatos eram homens. Minha fascinação originária com a Etiópia foi intensificada por uma forte paixão por um homem etíope. Homens, homens, homens. Mulheres, nesse mundo de homens, eram secretárias, serviçais, parentes, - para mim eram efetivamente "não pessoas"11.

Tudo agora havia mudado. Se as mulheres mais próximas, com exceção de Sofia, a esposa de Benjamin, haviam até então recuado, servido, ficado quietas, olhado para baixo, sido `simpáticas', agora elas se ergueram, saíram das sombras, me olharam diretamente nos olhos, falaram com franqueza e foram furiosamente cínicas.

\footnotetext{
${ }^{10}$ Esse ditado era parte do motivo pelo qual eu não esperava nenhuma ajuda mesmo se alguém ouvisse meus gritos.

${ }^{11}$ Para ser sincera, isso não era muito diferente de como eu via o sentido e as consequências das coisas em meu país.
} 
O que elas disseram foi simplesmente que isso é o que todas nós sofremos por sermos mulheres. Enquanto formos mulheres estaremos à mercê dos homens. Eu não tinha que me sentir envergonhada ou infeliz. O que tinha acontecido comigo era terrível e medonho, mas, infelizmente, normal. "Por sermos mulheres..."

Depois do estupro, as mulheres me contaram muitas histórias de violência sexual cometidas por homens. A falta de confiança que elas tinham nos homens era absoluta. Para muitas mulheres, a perspectiva de uma vida feliz consistia na possibilidade de uma vida sem vínculos permanentes com homens. Independência econômica, rodeada por uma família própria, amantes caso quisessem, mas sem homens com direitos de casamento ou algo do tipo - esse era o objetivo utópico delas.

Eu me senti culpada e envergonhada por ter assimilado a visão masculina do mundo, e a ideia de uma guerra entre os sexos, esboçada pelas mulheres com as quais conversei, foi estranhamente reconfortante. Nas minhas conversas com as mulheres, frequentemente o foco não recaía sobre mim, mas na desigual organização sexual de dependência feminina, segundo a qual sexo e serviços domésticos eram trocados por segurança econômica, e segundo a qual a mulher dependente perde sua determinação pessoal quando se submete a um vínculo com um único homem. O homem, nesse contrato, não perde nada além de possivelmente sua paz de espírito por temer ser substituído por um homem mais rico, mais poderoso, e devido a isso mais atraente.

\section{Minhas próprias reações ao estupro}

Depois do estupro, eu fui avassalada por uma enxurrada de informações sobre relações de gênero e sexualidade, mas eu não estava em posição de gravar, entender, ou utilizar esse material. Me senti nua, uma simples cidadã, desertora do campo antropológico. Qualquer ideia de que eu deveria usar minha situação para fins antropológicos me parecia blasfêmica, uma continuação da situação do estupro. Não havia nada de profissional naquilo que eu estava vivenciando. Eu mal conseguia me manter inteira. Eu dependia de meu ambiente para minha segurança e minha saúde mental. O estupro havia invertido uma hierarquia na qual até então eu ocupava uma posição dominante enquanto pesquisadora, profissional e estrangeira. Agora eu era somente uma mulher, buscando ter outras mulheres por perto para obter orientação, segurança e aconselhamento.

Logo após a agressão, eu passei por sentimentos de dois tipos. Um deles era como uma fúria tremenda. Se eu tivesse pego a arma que meu amigo Michael queria ter me emprestado, sinto que teria sido capaz de atirar em cheio em Yonas. Essa raiva ficou em mim por muitos anos.

O outro tipo era um medo imenso. Parte dele era irracional. Eu sentia que ia morrer só de olhar para Yonas novamente. Agora eu sei que essa é uma reação típica de sobreviventes de estupros. Provavelmente parte do medo era 
bem fundada. Yonas tinha determinado que me puniria e construiu um plano elaborado de como isso iria ocorrer. O plano dele havia falhado. Se ele havia começado a se sentir humilhado com a minha recusa de aceitá-lo sexualmente, a humilhação dele tinha sido acrescida de diversas camadas. Os que eram socialmente inferiores a ele o tinham questionado, desobedecido e se recusado a aceitar a definição dele das nossas relações. Ele tinha sido desarmado por um empregado. Ele tinha sido iludido e enganado. Ele tinha falhado sexualmente. E eu sabia de tudo isso e poderia facilmente revelar essas informações.

Minha intuição dizia que eu estava muito mais em perigo depois do ataque do que antes, e que eu continuaria em perigo até que eu estivesse fora do país, a um continente de distância. Ou até que um de nós estivesse morto.

Como eu mencionei anteriormente, usei um gerente regional de um dos bancos nacionais como um intermediário para estabelecer contato primeiro com conhecidos de Yonas e depois com ele mesmo. Yonas finalmente concordou em assinar um documento me liberando de ulteriores obrigações, mas para fazê-lo ele demandou dois meses de pagamento e uma carta de recomendação. Eu paguei e escrevi a recomendação. Ele teve inclusive a audácia de alterar a carta ${ }^{12}$.

Os dias até que esses assuntos fossem resolvidos foram dias de pânico. Eu me lembro de ficar acocorada dentro do banheiro trancado por horas, na casa da minha anfitriã, não ousando ficar sozinha no resto da casa nem por um minuto. 'Há pessoas que conseguem lidar e pessoas que não conseguem', ela me disse, relembrando incidentes em seus quinze anos como diretora em uma escola na Tanzânia. Eu não tinha certeza de ser daquele tipo das que conseguem lidar.

Com os papéis assinados eu me senti livre para deixar o país. Devolvi a mobília alugada e vendi os utensílios de casa que haviam sobrado. O material pesquisado eu deixei guardado com amigos. Fiz um acordo com Benjamin para continuar pagando o salário dele e transferi a casa para seu sobrinho. Então retornei para meu país de origem para me recuperar.

Eu voltei para Etiópia dois meses depois, com minha moral reforçada pela

\footnotetext{
${ }^{12}$ Nunca me ocorreu que haveria de fato uma alternativa para resolver a situação do modo etíope no qual eu me inseria. Eu poderia ter bancado bem a estrangeira - envolvendo a embaixada e a universidade que havia patrocinado minha estadia, invocado todas aquelas belas cartas de permissão e proteção que haviam circulado na estrutura burocrática antes de minha chegada em Ketema. De fato, enquanto eu sentia que estava somente pairando em Ketema, falhando miseravelmente na minha missão antropológica, eu estava afinal adquirindo um conhecimento completo de muitos aspectos salientes da vida urbana na Etiópia. Talvez observação participante seja muitas vezes isso. Nós voltamos nossas mentes para objetivos pré-estabelecidos de pesquisa, trabalhados bem antes de chegarmos em ca mpo, e dessa forma não sabemos apreciar o conhecimento e os insights que nos aparecem, por serem insights e conhecimentos 'errados', não nossos objetivos primeiros que havía mos nos proposto e tínhamos interesse de estudar.
} 
presença da minha mãe e do meu companheiro sueco, que há muito já planejava me visitar em campo de qualquer forma. Durante todo o mês que me visitaram eu me perguntava se seria capaz ou não de retomar as atividades e de continuar trabalhando em Ketema. Ao final eu decidi ficar.

Terminei uma segunda fase de pesquisa tipo survey em Ketema, o que levou alguns meses a mais. Sem Yonas me isolando eu consegui um grande número de contatos na cidade e teria conseguido facilmente fazer um trabalho mais intensivo se meu equilíbrio mental não estivesse tão precário. Parecia que o drama do estupro tinha me tornado uma pessoa real aos olhos dos moradores da cidade, que certamente haviam debatido os eventos durante minha ausência. Eu não senti falta de respeito ou julgamentos morais sobre mim, o que, obviamente, não significava que opiniões negativas estivessem ausentes. Depois de quatro meses meu tempo acabava e eu deixei a Etiópia.

Eu lidava bem com a situação desde que eu estivesse em Ketema, que ironicamente se tornou o único lugar na Etiópia onde eu me sentia realmente segura, já que eu estava convencida de que Yonas não ousaria aparecer na cidade novamente. De volta a Suécia, após o trabalho de campo, todavia, eu sofri com uma reação tardia. Em parte, isso era similar ao que qualquer sobrevivente a estupros passa. Eu tive pesadelos por anos, e por muitos meses eu não conseguia pensar em mais nada. Sentimentos "normais" de culpa eram exacerbados por pensamentos de que eu mesma tinha criado aquela situação, que eu tinha de fato colocado Yonas no papel de estuprador. Emocionalmente, de alguma forma eu sentia que Yonas tinha o direito de querer vingança. De fato, foi só durante o período da escrita desse capítulo que finalmente se iluminou para mim que foi Yonas quem havia tramado toda a relação desde o momento que ele soube de uma mulher estrangeira procurando um assistente. Eu sabia disso desde que ouvi a história de Yonas naquela fatídica noite. Contudo, de alguma forma, só agora entendi o que isso significa.

\section{Discussão}

Apesar dos vinte e poucos anos desde o começo da segunda onda da antropologia feminista, e apesar do fato de que 'gênero', como consequência disso, foi definitivamente trazido para muito do entendimento e da análise antropológica, a antropologia ainda não compreendeu o fato de que antropólogos são eles mesmos marcados por gênero ${ }^{13}$. A demografia da antropologia social e cultural é similar a de muitas outras disciplinas das humanidades e das ciências sociais: há uma maioria de jovens mulheres entre estudantes, mas uma proporção gradualmente decrescente de mulheres quanto mais nos aproxi-

${ }^{13}$ Certamente há várias outras distinções largamente ignoradas ou não reconhecidas. 
mamos do topo da hierarquia acadêmica (Sanjek, 1982). Esse tipo de estrutura de pirâmide generificada garante que a predominância feminina em números não se traduza em uma correspondente influência no ambiente acadêmico.

Antropólogos 'em casa', nas universidades e departamentos, e nas nossas vidas fora das instituições acadêmicas são parte de ordenamentos específicos de gênero que correspondem aos tempos e sociedades nas quais vivemos. Contudo, um aspecto central da vida acadêmica, é a negação de gênero no trabalho. Isso quer dizer que se espera que estudemos, administremos, escrevamos e ensinemos como se gênero não importasse. Essa ficção faz parte integral da vida acadêmica e pode ser sustentada porque nós só passamos parte de nossas vidas na universidade. Nós deixamos o mundo alegadamente "sem gênero" da academia no fim do dia e saindo dali assumimos uma grande variedade de papéis de gênero. Alguns vão para casa para colocarem seus pés para cima, ler o jornal da noite, e mergulhar nas últimas revistas antropológicas depois que o jantar foi providenciado. Outras vão para casa para ir ao mercado, cozinhar, lavar louças, lavar roupas e tudo que for necessário para que a vida siga ${ }^{14}$.

Para antropólogas mulheres, uma das consequências da ficcional vida 'sem gênero' que levamos na universidade é que, se levantamos questões que são específicas para nós enquanto mulheres no contexto acadêmico, nós corremos o risco de danificar nossas identidades como antropólogas. Isso acontece, certamente, porque o antropólogo arquetípico é um homem. Parte da agenda oculta para antropólogas mulheres consiste, portanto, em evitar chamar atenção para nós mesmas enquanto mulheres quando estabelecemos nossas identidades profissionais. Afinal de contas, quem quer ser uma antropóloga mulher quando é possível ser um antropólogo 'de verdade ${ }^{15}$ ? No que tange a violência sexual, isso pode ser parte da vida cotidiana de uma mulher, mas isso não é visto como relevante na parte profissional de nós mesmas - na parte 'antropólogo'. 'Antropólogos' não são assediados ou estuprados. Mulheres são.

Em campo, a falsa divisão de tempo e espaço entre o 'profissional' e o 'privado’ subjacente à identidade neutra do antropólogo colapsa completamente. Em campo não é possível manter a ficção do self sem gênero. Não é possível ser 'antropólogo' sem marcações. Em campo as pessoas são marcadas. As pessoas são percebidas e se percebem a si como antropólogo marcado por gênero

\footnotetext{
${ }^{14}$ Mikaela di Leonardo escreve nos agradecimentos de sua antologia de 1991: "Muitos dos autores (e eu) são mulheres da "geração sanduíche": especialmente sujeitas a crises médicas e pessoais - e àquelas de nossos pais e nossos filhos” (DI LEONARDO, 1991, p. xi). Nem é preciso dizer que não há uma "geração sanduíche" para homens.

${ }^{15}$ Dorothy Smith cunhou a expressão "consciência bifurcada” para descrever como mulheres nas Ciências Sociais conseguem participar da empreitada acadêmica que nega a validade da nossa experiência de vida enquanto mulheres, e que nos leva a aceitar definições masculinas de padrões acadêmicos na teoria e na prática de nossas disciplinas (SMITH, 1987, p. 6).
} 
- uma antropóloga mulher ou um antropólogo homem. E enquanto antropólogos marcados por gênero, nós não somos somente atraentes para outras pessoas ou sentimos atração - nós também podemos ser alvo de violência sexual: violência que é dirigida, assim como foi no meu caso, tanto para nosso ser 'profissional' como para nosso ser 'privado' (onde mesmo está a diferença?).

Os significados multidimensionais das relações sexuais em campo nunca são os mesmos para antropólogas mulheres e antropólogos homens. O silêncio lancinante de homens heterossexuais sobre esse assunto é em si sinistramente significativo. Relatos de campo de mulheres frequentemente mencionam aspectos sexuais da situação de campo, provavelmente porque em muitos campos a problemática sexual é lançada às antropólogas e molda o tipo de trabalho que podemos fazer. A possibilidade de violência sexual, explícita ou implícita, é uma forma pela qual o movimento e as atividades de mulheres são restritas em muitos contextos sociais, e é, portanto, uma temática que muitas antropólogas mulheres têm que lidar, enquanto antropólogos homens não precisam ${ }^{16}$. A questão sobre manter ou não relações sexuais em campo é algo que muitas antropólogas mulheres têm que enfrentar, não ocasionalmente, ou uma vez ou outra, mas basicamente de forma continuada, pelo fato de que homens como Yonas pedem, importunam e exigem. Tudo isso é diferente para homens. Outras atividades sexuais também são diferentes. Sexo comercial, por exemplo, pode estar acessível para homens mas nunca para mulheres.

O estupro é uma relação vil e assassina. $\mathrm{O}$ estupro cria um abismo na compreensão mútua entre mulheres e homens. O desejo de estuprar é de impossível compreensão para mulheres, e as consequências do estupro para a vítima-sobrevivente podem ser, para os homens, igualmente difíceis de compreender e de por elas sentir empatia. Sendo esse o caso, talvez não seja estranho que estupro tenha permanecido um 'não assunto' dentro da nossa disciplina, deixando de lado todas as outras considerações. Quando eu retornei para o meu departamento na Suécia após o ataque na Etiópia, eu contei aos meus colegas o que havia ocorrido. Todas as minhas colegas expressaram choque, preocupação e apoio. Por outro lado, as duas pessoas que faziam a supervisão acadêmica (ambos homens), me escutaram contar várias vezes a história da agressão, mas apresentaram pouca empatia e nunca mais mencionaram o assunto do estupro. Depois eu soube que um deles disse a uma estudante de pós-graduação que eu devia ter agido como uma tola em campo. Outro antropólogo sênior, ao ouvir sobre o estupro suspirou 'Essas coisas acontecem com mulheres em campo'.

Quando eu me organizei para fazer campo em 1970, eu trabalhei na Etiópia sem entender que meu próprio gênero poderia ser um fator importante

\footnotetext{
${ }^{16}$ A não ser quando estão acompanhados por esposas ou filhas. Mas, novamente, isto é 'privado', e eles podem não considerar que sua segurança faz parte do trabalho de campo.
} 
no trabalho de campo que eu faria. Tudo que eu havia ouvido sobre o assunto era meu supervisor me dizendo que etnógrafas tinham vantagens sobre etnógrafos porque antropólogas mulheres costumavam ter acesso a ambos os círculos sociais, feminino e masculino. Na realidade, os caminhos abertos para antropólogas mulheres varia de um campo para outro, assim como variam os contextos dos antropólogos e o ajuste entre eles o campo.

O que não varia é o fato de que mulheres devem sempre, em qualquer lugar, lidar com o espectro da violência sexual de uma forma que se diferencia fundamentalmente de qualquer coisa que nossos colegas homens tenham que se deparar. Isso não significa que violência sexual é, por definição, 'um problema das mulheres'. Pelo contrário, estupro é certamente parte de uma problemática profundamente masculina. E o ponto deste capítulo é que, seja lá o que violência sexual contra antropólogos/antropólogas possa ser, ela é por definição um problema antropológico. Diz respeito a todos nós, mulheres e homens, e isso lhe assegura um lugar importante na agenda antropológica mainstream.

\section{Posfácio}

Muito depois de esse capítulo ter sido concluído e enviado para os editores com o manuscrito do livro, eu me deparei repentinamente com outra, bastante inesperada razão pela qual violência sexual em campo é tão raramente discutida na literatura antropológica. Logo antes das provas ficarem prontas, a Routledge me contatou e sugeriu que minha contribuição fosse alterada para tornar 'Yonas' ainda mais impossível de identificar. Chamá-lo por um pseudônimo, como eu havia feito (e continuo fazendo), não foi considerado suficiente para afastar uma possibilidade de processo sobre calúnia contra a Routledge por parte de 'Yonas' - mesmo que os acontecimentos descritos no meu trabalho tenham acontecido há vinte anos e em um país no qual, como eu havia colocado, o direito não reconhecia estupro como um crime contra mulheres que não fossem comprovadamente virgens. Ao invés de introduzir elementos ficcionais no texto, que teriam distorcido as dinâmicas das situações que afinal levaram ao estupro, eu optei por publicar o capítulo usando um pseudônimo para mim mesma. Meu uso de um pseudônimo é, dessa forma, não para proteger minha própria identidade, mas, ao invés disso (e eu espero que o peso da ironia não esteja perdido em ninguém), para proteger a identidade do estuprador.

\section{Agradecimentos}

Eu gostaria de agradecer a Margaret Willson e a Don Kullick pelo encorajamento e pela colaboração que me ofereceram na escrita deste capítulo. 


\section{Referências Bibliográficas}

BROWNMILLER, Susan. Against Our Will: Men, Women and Rape. New York: Simon and Schuster, 1975.

DI LEONARDO, Micaela. 'Introduction'. In Gender at the Crossroads of Knowledge: Feminist Anthropology in the Postmodern Era. Berkeley, Calif.: University of California Press, 1991.

FREEDMAN, Diane. 'Wife, Widow, Woman: Roles of an Anthropologist in a Transsylvanian Village'. In GOLDE, Peggy (ed.) Women in the Field: Anthropological Experiences. Berkeley, Calif.: University of California Press, 1986.

HOWELL, Nancy. Surviving Fieldwork: A Report of the Advisory Panel on Health and Safety in Fieldwork. Special Publication of the American Anthropological Association No 26. Washington, D.C.: American Anthropological Association, 1990.

KAPUSCINSKI, Ryszard. The Emperor: The Downfall of an Autocrat. New York: Harcourt Brace Jovanovich, 1983.

KULICK, Don. 'Response to David Lipset's letter to Anthropology Today, December 1993'. Anthropology Today. Vol. 10. No. 1, 1994, p. 13.

LANDES, Ruth. 'A Woman Anthropologist in Brazil'. In GOLDE, Peggy (ed.) Women in the Field: Anthropological Experiences. Berkeley, Calif.: University of California Press, 1986.

MARKAKIS, John. Ethiopia: The Anatomy of a Traditional Polity. London: Oxford University Press, 1974.

SANJEK, Roger. 'The AAA Resolution on the Employment of Women: Genesis, Implementation, Disavowal an Resurrection'. Signs: Journal of Women in Culture and Society. Vol. 7, No. 4, 1982, pp. 845-68.

SMITH, Dorothy E. The Everyday World as Problematic: A Feminist Sociology. Milton Keyes: Open University Press, 1987.

WENGLE, John L. Etnographers in the Field: The Psychology of Research. Tuscaloosa, Ala.: University of Alabama Press, 1988.

WINKLER, Cathy. 'Rape as Social Murder'. Anthropology Today. Vol. 7. No. 3, 1991, pp. 12-14.

\section{autora Eva Moreno}

Um pseudônimo, foi professora e realizou pesquisa em uma universidade sueca. 